DOI: 10.34015/2523-4552.2019.4.09

удк 347.73

Гусейнов I. В.,

аспірант кафедри державно-правових

дисциплін Харківського національного

університету імені В. Н. Каразіна

e-mail:mr.ilgarhuseynov@gmail.com

ORCID: 0000-0001-7984-5599

\title{
СТАДІЇ ТА ЕЛЕМЕНТИ МЕХАНІЗМУ РЕАЛІЗАЦІї НОРМ ФІНАНСОВОГО ПРАВА
}

Наукова стаття присвячена питанням механізму реалізації фінансовоправових норм, виокремленню його стадій та виділенню елементів.

Ключові слова: механізм реалізації; фінансові правовідносини; норма права; фінансово-правова норма.

Научная статья посвящена исследованию вопроса механизма реализации финансово-правовых норм, выделению его стадий и элементов.

Ключевые слова: механизм реализации; финансовое правоотношение; норма права; финансово-правовая норма.

Постановка проблеми. Механізм реалізації норм фінансового права складається 3 певних стадій, яким відповідають головні, найбільш типові елементи, які $\epsilon$ властивими для кожній стадії. В структуру даного механізму також можуть включатися факультативні елементи, які забезпечують найбільш повний ефект і результативність його функціонування. Для розкриття внутрішньої логіки цього процесу, який дозволяє представити максимально конкретно і точно процес такої реалізації і його базові, вузлові моменти, об'єктивні передумови і роль різних суб'єктів фінансового права в його фактичному здійсненні необхідно саме виділення стадій механізму реалізації норм фінансового права.

Аналіз останніх досліджень і публікацій. Проблеми механізму реалізації норм фінансового права в тій чи іншій мірі були предметом дослідження в роботах різних вчених, серед яких необхідно відзначити найбільш відомих: І. Я. Дюрягіна, С. В. Запольського, Г. В. Россіхіну та ін. Водночас, у дослідженні зазначеного питання виокремлення стадій та виділення елементів механізму реалізації норм фінансового права науковцями не здійснювалось.

Постановка завдання. Внаслідок чого, метою даної статі $є$ дослідження стадій та елементів механізму реалізації норм фінансового права.

Виклад основного матеріалу. Будь-який розподіл багатоступінчатого і складного процесу реалізації вимог фінансового права на стадії $\epsilon$ досить умовним в цілому. Стадійна характеристика управлінського фактору й явища $є$ об'єктивним інструментом його дослідження і розумін- 
ня, але все-таки в плані науковообгрунтованої політики побудови й використання на практиці відповідного механізму його розгляд у розрізі стадій вельми є актуальним. Кожна стадія передбачає, як мінімум, декілька базових параметрів опису, які можна одночасно визначати і як елементи однойменного механізму.

По-перше, стадія процесу, процедури, механізму, виробництва та будь-якого юридичного явища $\epsilon$ немислимою без такого елементу як суб’єкти, які приймають участь на даній стадії і з діяльністю яких дана стадія позиціонується. Інакше кажучи, конкретний суб'єкт фінансового права є особливою «карткою» даної стадії. Наприклад, згідно Закону України «Про Кабінет Міністрів України» [1] одним 3 його завдань є забезпечення проведення бюджетної, фінансової, цінової, інвестиційної, у тому числі амортизаційної, податкової, структурно-галузевої політики; політики у сфері праці та зайнятості населення, соціального захисту, охорони здоров'я, освіти, науки і культури тощо. Кабінет міністрів України регулярно інформує громадськість через засоби масової інформації про свою діяльність, залучає громадян до процесу прийняття рішень, що мають важливе суспільне значення. Згідно нормам Бюджетного кодексу України на стадії складання Бюджетної декларації та проекту Державного бюджету України Кабінет Міністрів України розробляє зазначену декларацію та відповідний проект. Також дана стадія бюджетного процесу закінчується тим, що Кабінет Міністрів України схвалює проект закону про Державний бюджет України та подає його разом з відповідними матеріалами Верховній Раді
України та Президенту України не пізніше 15 вересня року, що передує плановому. Вже на стадії розгляду та затвердження Державного бюджету України протягом трьох днів 3 дня прийняття Верховною Радою України закону про Державний бюджет України Кабінет Міністрів України подає Президенту України обгрунтування і розрахунки щодо бюджетних показників такого закону, змінених порівняно 3 проектом закону про Державний бюджет України, поданим Кабінетом Міністрів України до Верховної Ради України на розгляд у першому читанні. Якщо Президент України повернув до Верховної Ради України для повторного розгляду закон про Державний бюджет України із вмотивованими і сформульованими пропозиціями, які передбачають зміни бюджетних показників, Кабінет Міністрів України у тижневий строк подає Верховній Раді України зміни до показників, зазначених у текстових статтях такого закону, та оновлені додатки до нього відповідно до пропозицій Президента України. В свою чергу стадія виконання Державного бюджету України передбачає участь Кабінету Міністрів України в забезпеченні виконання Державного бюджету України. I вже на останній стадії бюджетного процесу річний звіт про виконання закону про Державний бюджет України подається Кабінетом Міністрів України Верховній Раді України, Президенту України та Рахунковій палаті не пізніше 1 квітня року, наступним за звітним [2].

По-друге, стадія механізму правореалізації виділяється також тому, що вона спрямована на досягнення певних цілей і вирішення конкретних завдань, які стоять в даний мо- 
мент часу перед органом державного управління в тій або іншій сфері. Наприклад, в Україні незабаром буде створено службу (Бюро) фінансових розслідувань, яка об'єднає всі компетентні органи протидії економічним злочинам в одне потужне відомство. Метою створення даної служби $\epsilon$ запровадження європейської моделі фінансового контролю внутрішнього аудиту розпорядників бюджетних коштів після відкриття кримінального впровадження. Даний орган повинен остаточно ліквідувати податкову міліцію та запровадити замість неї нову службу - Національне бюро фінансової безпеки. 22 березня 2017 року ухвалено Кабінетом Міністрів України проект закону «Про Бюро фінансових розслідувань». Це буде єдиний ефективний правоохоронний орган, що займатиметься виявленням, припиненням, розкриттям та досудовим розслідуванням злочинів, які спрямовані проти інтересів держави у сфері фінансів та суміжних сферах. До того ж даний орган буде займатися аналітичною роботою, виявляти системні чинники, що сприяють розвитку економічної злочинності та вчиненню таких злочинів і надавати на основі такого аналізу пропозиції Міністерству фінансів України щодо формування державної політики з метою забезпечення ефективної превенції економічних злочинів [3].

По-третє, певну стадію завжди характеризує відносно самостійний, відокремлений або завершений набір однорідних юридичних дій, операцій суб'єктів фінансового права. В свою чергу відзначені дії, операції облікаються саме в установлену законом процесуальну форму. Практично завжди владні суб'єкти фінансо- вого права видають індивідуальні фінансово-правові акти, які необхідні для вирішення завдань тієї або іншої стадії. Вони покладають на суб'єктів, які приймають в них участь, індивідуальні права і обов'язки. На думку С. В. Запольского, фінансово-правові акти, що створюють правову основу фінансової діяльності, за своїми юридичним властивостями можна поділити на три групи, а саме: 1) нормативні фінансові акти (які встановлюють загальні правила поведінки для суб'єктів - фізичних і юридичних осіб, що здійснюють фінансову діяльність; звернені до широкого кола фізичних і юридичних осіб; розраховані на тривалий час дії); 2) індивідуальні фінансові акти - державновладні приписи щодо питань фінансової діяльності, які розраховані тільки на певний, виключно індивідуальний випадок і звернені тільки до поіменно вказаних осіб; 3) фінансово-планові акти приймаються в процесі фінансової діяльності, які містять конкретні завдання у сфері фінансів на певний період [4, c. 21-22].

Загальновідомо, що за порушення законів з питань оподаткування та іншого законодавства, контроль за дотриманням якого покладено на контролюючі органи, застосовуються такі види юридичної відповідальності: фінансова, адміністративна, кримінальна [5, ст. 111]. Фінансова відповідальність застосовується у вигляді штрафних (фінансових) санкцій (штрафів) або пені. Штрафи включаються до поняття грошового зобов'язання платника податків. Граничні строки застосування штрафних (фінансових) санкцій (штрафів) до платників податків відповідають строкам давності для 
нарахування податкових зобов'язань, визначених податковим законодавством. Грошове зобов'язання може бути нараховане або провадження у справі про стягнення такого податку може бути розпочате без дотримання визначеного строку давності, якщо згідно чинного законодавства:

- податкову декларацію за період, протягом якого виникла податкове зобов'язання, не було подане;

- посадову особу платника податків (фізичну особу-платника податків) засуджено за ухилення від сплати зазначеного грошового зобов'язання або у кримінальному провадженні винесено рішення про його закриття 3 нереабілітуючих підставах, яке набрало законної сили.

У разі застосування контролюючими органами до платника податків штрафних (фінансових) санкцій (штрафів) за порушення законів 3 питань оподаткування та іншого законодавства, контроль за дотриманням якого покладено на контролюючі органи, такому платнику надсилаються (вручаються) податкові повідомлення-рішення [5, ст. 116.1]. Згідно статті 57 Податкового кодексу України у разі визначення грошового зобов'язання контролюючими органами за підставами, зазначеними нормами податкового законодавства, платник податків зобов'язаний сплатити нараховану суму грошового зобов'язання протягом 10 календарних днів, що настають за днем отримання податкового повідомлення-рішення, крім випадків, коли протягом такого строку платник податків розпочинає процедуру оскарження рішення контролюючого органу. Якщо платник податків не сплатив у встановлені строки суму: узгодженого грошового зобов'язання або непогашеної пені, нарахованої у порядку, визначеному податковим законодавством, формується податкова вимога. Засобами забезпечення виконання податкового обов'язку на сьогодні є: податкова застава, адміністративний арешт майна тощо [5]. В даному випадку дія механізму реалізації фінансово-правових норм на конкретній іiі стадії виконання рішення контролюючих органів щодо визначення суми податкових та грошових зобов'язань виявляється у встановленні порядку здійснення юридично значущих дій уповноважених органів (моніторинг строків добровільної сплати штрафу, спрямування податкового повідомлення рішення, складання податкової вимоги тощо).

Таким чином, аналіз механізму реалізації норм фінансового права, як ми вже встановили, повинен здійснюватися за допомогою стадій i відповідних їм елементів, які виділяються за об'єктивними критеріями специфічних суб'єктів, цілей і завдань кожної стадії, а також юридичної однорідної діяльності, яка оформлюється в конкретних матеріально і процесуально-правових актах.

Саме тому можна визначити в якості стадії механізму реалізації норм фінансового права відносно самостійний етап руху фінансовоправової норми, починаючи від формування поводів і підстав для їі втілення в практику, виникнення потреб і законних інтересів учасників фінансових відносин в реалізації норми фінансового права, аж до практичного її здійснення у поведінці суб'єктів фінансового права. В якості елементів механізму реалізації фінансово-правових норм необхідно 
розглядати фінансово-правові явища, які забезпечують фактичне втілення до життя вимог вказаних норм і виступають в якості інструментів, інститутів і діянь (технологій) щодо досягнення названих цілей.

Питання про найменування i кількість стадій, елементів механізму реалізації норм фінансового права $є$ досить дискусійним. Як вже відзначалося раніше, ототожнення цього механізму з механізмом фінансовоправового регулювання суспільних відносин $€$ вірним лише частково 3 точки зору їх співвідношення як цілого і частини, але яка відповідає за правильне і ефективне втілення до життя фінансово-правових приписів органів публічної влади. У зв'язку з цим, якщо приймати до уваги, загальну структури побудови механізму фінансово-правового регулювання відносин в сфері обігу публічних коштів ( норма фінансового права - акт тлумачення і застосування норми фінансові правовідносини), то стадії механізму реалізацій норм фінансового права, на наш погляд, повинні виглядати наступним чином:

а) стадія формування потреб i законних інтересів суб'єктів фінансового права;

б) стадія виникнення і здійснення суб'єктивних прав і юридичних обов'язків громадян, організацій, посадових осіб і органів публічної влади у сфері фінансової діяльності держави;

в) стадія контролю за реалізацією норм фінансового права. Має сенс надати стислу характеристику кожній окремій стадії механізму реалізації норм фінансового права. Так, першою є стадія формування потреб і законних інтересів суб'єктів фінансового права. Необхідно відзначити, що дана стадія фактично не виділяється вченими-фінансистами. Але дана стадія $є$ важливою для розуміння того, що людина живе в нормативно врегульованому правовому просторі, а потреба в тій або іншій реалізації вимог фінансового права виникає у нього у зв'язку з нормами, які вже функціонують.

Треба відзначити, що існує певна необхідність при прийнятті рішень в сфері публічних фінансів саме у врахуванні приватних і публічних інтересів. Загальновідомо, що приватний сектор безпосередньо не $є$ об'єктом фінансово-правового регулювання. Але через різні канали впливу в державно-правовому механізмі приватний капітал істотно впливає на визначення фінансового курсу. При формуванні фінансової політики держави максимально повний облік інтересів приватного капіталу $є$ необхідною умовою як для суб'єктів підприємницької діяльності, так і органів державної влади і місцевого самоврядування. Основні орієнтири фінансової політики, як-то ставка рефінансування, рівень оподаткування, валютний курс тощо, безпосередньо впливають на результати діяльності учасників приватного сектору. В свою чергу, держава повинна розуміти, що без участі ділового кола у формуванні фінансової політики істотно знижається легітимність фінансового законодавства. Це в свою чергу призводить до збільшення долі протиправної поведінки в сфері публічних фінансів за рахунок представників приватного бізнесу. Тобто фінансовоправове регулювання практично охоплює майнові інтереси практично всіх груп населення.

Другою є стадія виникнення i здійснення суб'єктивних прав і юри- 
дичних обов'язків громадян, юридичних осіб, посадових осіб і органів публічної влади в сфері фінансової діяльності держави. Це основна стадія, на якій відбувається реалізація норм фінансового права у власному розумінні цього терміну. У багатьох випадках існує необхідність спеціально забезпечити реалізацію цих норм у порядку правозастосовної діяльності. І. Я. Дюрягін підкреслює, що в цілому ряді випадків неможливо досягнути повної реалізації правових норм без втручання в цій процес компетентних органів, тобто без застосування правових норм, яке складається у вирішенні даними органами конкретних юридичних справ і винесенні відповідних рішень. По-перше, застосування норм права необхідно тоді, коли передбачені ним суб'єктивні права i обов'язки такі, що не можуть виникнути у конкретних осіб із односторонніх заяв, угод або договорів. Подруге, застосування правових норм становиться необхідним, коли належним чином виконуються юридичні обов'язки або виникає спір про право. По-третє, без правозастосовної діяльності не можуть бути реалізовані норми, які передбачають притягнення правопорушників до юридичної відповідальності і здійснення необхідних для цього допоміжних дій (слідчих дій, дій щодо виконанню договору тощо) [6, с. 32].

Специфіка виділення даної стадії складається в тому, що в контексті фінансової правореалізації вона фактично об'єднує дві традиційні ступені, а саме: виникнення прав і обов'язків суб'єктів фінансового права та їх здійснення. I такий підхід нам уявляється правильним. Механізм реалізації фінансово- правових норм - це складова частина загального механізму фінансовоправового регулювання суспільних відносин, який функціонально спрямований на супроводження і забезпечення практичного здійснення даних норм в суспільному житті і управлінської практики. Саме тому, практична необхідність розмежування цих стадій, яка є властивістю механізму фінансово-правового регулювання, $\epsilon$ відсутньою. Особливість ж реалізації нормативних приписів у фінансовому праві найбільш точніше виявляється тоді, коли виникнення і здійснення передбачених ним прав і обов'язків взаємно узгоджені один 3 іншим, складають разом єдиний процес, який прийнято називати «реалізацією права».

Третьою є стадія контролю за реалізацією норм фінансового права. Ïї виділення також уявляється не всім вченим ясним і однозначним перш усього звичайно заперечують дану стадію теоретики права. Як стверджується цими вченими в рамках дослідження правозастосовного процесу, виконання правозастосовного акту являє собою діяльність інших органів і посадових осіб держави, що здійснюється в інших процедурно-процесуальних формах i виражається в специфічних правоохоронних актах, у зв'язку з чим не може існувати «правозастосування в правозастосуванні» [7].

Контроль і нагляд за виконанням фінансових зобов'язань, які забезпечуються можливістю застосування фінансових санкцій, здійснюються спеціальними органами держави і місцевого самоврядування. На сучасному етапі найбільш ефективними формами фінансового контро- 
лю і державного нагляду є надвідомчі форми. Виявлені в ході фінансового контролю і державного нагляду порушники фінансового законодавства підлягають фінансовим санкціям цими або іншими органами. При цьому органи фінансового контролю самостійно застосовувати фінансові санкції не можуть, в той час як наглядовим органами таке правило, як правило, надається.

Парламентський контроль здійснюється законодавчими органами державної влади і представницькими органами місцевого самоврядування (в першу чергу, при розгляді і затвердженні проектів бюджетів і звітів про їх виконання). 3 цією метою в структурі законодавчих i представницьких органів створюються комісії з питань бюджету, податків, фінансів, планування та соціально-економічного розвитку (бюджетні комісії). До завдань яких входять перевірка законності, обгрунтованості і повноти державних доходів і видатків, які передбачені в бюджеті, їх ефективності і доцільності використання державних коштів. Законодавчі і представницькі органи можуть здійснювати вибірковий контроль через галузеві комітети і комісії, які перевіряють фінансову діяльність окремих ланок: публічного сектору фінансової системи. При необхідності депутати можуть створювати слідчі комісії будь-якого питання. При цьому підконтрольні органи, організації і посадові особи зобов'язані неухильно виконувати вимоги цих комісій і надавати їм необхідні документи і інформацію.

При законодавчих органах державної влади і представницьких органах місцевого самоврядування також можуть створюватися спеціа- льні контрольно-рахункові органи. Так, Рахункова палата України є фактично постійно діючим органом державного фінансового контролю, який діє від імені Верховної Ради Україні, підзвітна їй та регулярно їі інформує про результати своєї роботи.

Рахункова палата складається 3 дев'яти членів Рахункової палати. Членами Рахункової палати є Голова Рахункової палати, його заступник та інші члени Рахункової палати. Для забезпечення виконання покладених на Рахункову палату повноважень діє апарат Рахункової палати, що складається 3 департаментів, територіальних та інших структурних підрозділів (включаючи патронатні служби членів Рахункової палати). Рахункова палата у разі виявлення при здійсненні заходів державного зовнішнього фінансового контролю (аудиту) ознак кримінального або адміністративного правопорушення повідомляє про них відповідні правоохоронні органи. Відповідні правоохоронні органи за наслідками розгляду матеріалів Рахункової палати інформують їі про вжиті заходи реагування [8].

Особливе місце в системі органів загального фінансового контролю займає Міністерство фінансів Україні, яке здійснює багатогранну контрольну діяльність в процесі формування загальнодержавного бюджету - при розгляді проектів фінансових планів і кошторисів, на етапі його виконання - при акумуляції доходних надходжень і фінансування із бюджету видатків, а також при проведенні різних перевірок і ревізій. Фінансовий контроль покладений на різні підрозділи Міністерства фінансів, а також на спеціально ство- 
рений в його структурі контрольноревізійний апарат.

3 метою посилення контролю за надходженням, цільовим і ефективним використанням державних коштів в 1993 році почалося формування єдиної централізованої системи органів Державної казначейської служби, яка знаходиться у веденні Міністерства фінансів Україні. На сучасному етапі ця система включає до себе Казначейство, яке здійснює свої повноваження безпосередньо та через утворені в установленому порядку територіальні органи Казначейства: головні управління Державної казначейської служби України в Автономній Республіці Крим, областях, містах Києві та Севастополі та управління (відділення) Державної казначейської служби Україні в районах, районах у містах, містах обласного республіканського значення. Фактично на Державну казначейську службу покладена функція організації і здійснення оперативного (поточного) контролю за виконанням бюджету України, а також контроль за позабюджетними загальнодержавними коштами.

У 1992 році була створена одна 3 найбільш потужних служб фінансового контролю - податкова служба, яка призвана забезпечувати ефективний контроль за повнотою і своєчасністю перерахування податків до бюджету фізичними і юридичними особами. Державна податкова служба $\epsilon$ центральним органом виконавчої влади, діяльність якого спрямовується і координується Кабінетом Міністрів України через Міністра фінансів України і який реалізує державну податкову політику, державну політику 3 адміністрування єдиного внеску на загальнообов'язкове державне соціальне страхування. Державна податкова служба здійснює повноваження безпосередньо та через утворені в установленому порядку їі територіальні органи. Вказана служба та ії територіальні органи $\epsilon$ контролюючими органами (органами доходів і зборів).

До здійснення державного фінансового контролю в якості агентів залучаються банки і інші кредитні організації. Банківський контроль $\epsilon$ найбільш гнучкою і всеохоплюючою формою фінансового контролю за діяльністю клієнтів кредитних організацій, який здійснюється комерційними банками і небанківськими кредитними організаціями в ході здійснення банківських операцій. Цей вид фінансового контролю націлений на підвищення ефективності використання банківських кредитів і укріплення платіжної дисципліни. Поворотність кредиту створює основу для банківського контролю в процесі кредитування, а контроль, в свою чергу, служить необхідною умовою поворотності кредиту.

Висновки. Аналіз стадій і елементів механізму реалізації норм фінансового права є об'єктивно необхідним для розкриття змісту цього відносно нового поняття, яке прагне набути категоріальний статус в апараті науки фінансового права. Даний аналіз можна продовжити 3 точки зору функціональних характеристик цього механізму і виділення нормативно-інституціональних, процедурно-процесуальних і інструментальних його компонентів. 


\section{Список використаних джерел}

1. Про Кабінет Міністрів України: Закон України. Відомості Верховної Ради України. 2014. № 13. Ст. 222.

2. Бюджетний кодекс України. Відомості Верховної Ради України. 2010. № 5051. Ст. 572.

3. Про Бюро фінансових розслідувань: Проект Закону України. URL: http//w1.c1.rada.gov.ua.

4. Запольский С. В. Финансовое право: учебник. Москва : Юрид. фирма «Контракт», Волтерс Клувер. 2011. 792 с.

5. Податковий кодекс України. Відомості Верховної Ради України. 2011. № 1314, № 15-16, № 17. Ст. 122.

6. Дюрягин И. Я. Применение норм советского права. Теоретические вопросы. Свердловск : Средне-Уральское книжное изд-во, 1973. 245 с.

7. Россіхіна Г.В. Застосування фінансово-правових норм: монографія. Харків : «Цифрова друкарня № 1», 2013. 400 с.

8. Про Рахункову палату: Закон України. Відомості Верховної Ради України. 2015. № 36. Ст. 360.

\section{References}

1. Zapolskij, S. V. (2011) Finansovoe pravo. Moskva: Yurid. firma «Kontrakt», Volters Kluver [in Russian].

2. Dyuryagin, I. Ya. (1973). Primenenie norm sovetskogo prava. Teoreticheskie voprosy. Sverdlovsk: Sredne-Uralskoe knizhnoe izd-vo [in Russian].

3. Rossihina, G. V. (2013). Zastosuvannya finansovo-pravovih norm: monografiya. Harkiv: «Cifrova drukarnya № 1» [in Ukrainian].

I. Huseynov, graduate student of the Department of State and Legal Disciplines, V.N. Karazin Kharkiv National University

e-mail: mr.ilgarhuseynov@gmail.com; ORCID: 0000-0001-7984-5599

\section{Stages and elements of the financial law mechanism}

The article is devoted to the study of the question of the general characteristics of the mechanism of the implementation of financial and legal norms. The author concludes that the mechanism of realization of the norms of financial law is a set of normative acts, with the help of which the whole process of their implementation is implemented from the intent of the legislator to the adoption, implementation and actual implementation of the goals and objectives of legal regulation.

The mechanism of implementing the rules of financial law is a system of legal means, through which the effective legal effect on social relations that arise in the process of financial activity of the state is exercised. The mechanism of the implementation of financial law is in fact the activities of the relevant state bodies (subjects of power), organizations, private entities in relation to the decision of their goals and objectives with the powers (competences) entrusted to them, competences, prohibitions and duties provided their legal permissions. The concept 
of "mechanism of realization of the norm of law" was substantiated and investigated, features of the relation of financial legal relations and financial-legal norm as its regulator were determined. The norms of the current financial and tax legislation, features of financial and legal norms, and the mechanism of financial and legal regulation are analyzed.

Keywords: mechanism of realization; financial legal relations; norm of law; financial and legal norm. 